WIENER SLAVISTISCHES JAHRBUCH, Band 52/2006, 153-170

(C) 2007 by Österreichische Akademie der Wissenschaften, Wien

CAROLIN F. ROEDER

B JÖRN H A N S EN

\title{
Modals in contemporary Slovene
}

\section{Modals AS A FUZZY CROSS-LINGUISTIC CATEGORY}

In contrast to Germanic linguistics, 'modal' is not an established notion in either Slovene, or Slavonic linguistics. Many grammarians do not consider the expression of necessity, possibility and volition part of grammar and, consequently, do not recognise modals as a category in its own right. Frequently, modality is treated as a lexical phenomenon and no attempt is made to differentiate the exponents of modality. We propose to determine modals as means of expression of modality, which have undergone a certain degree of grammaticalization; they express the basic notions 'necessity', 'possibility' or 'volition' and can co-occur with most types of verbs. Modals are a specific type of auxiliary. They do not form a closed set and can only be determined by being located on a grammaticalization chain extending from content words to fully-fledged auxiliaries. An auxiliary "is no longer a fully lexical item, but not yet a grammatical inflection either, and it is likely to exhibit properties that are characteristic of the intermediate stages" between fully lexical items and inflectional forms (Heine 1993: 86). Modals form a category with a small core and a 'fuzzy' periphery exhibiting transitional zones to neighbouring categories.

Definition: A modal is a polyfunctional expression of modality. It always occurres with main verbs in the predicate position and opens one and only one argument position, which is filled by a lexical verbal stem. A modal does not select its own nominal arguments but takes over the argument structure of the verbal form. No selection restrictions are imposed on the main verb.

Modals are to be located at the 'grammatical periphery' (Plungian's term 2003: $130 \mathrm{ff}$.) and tend to form a kind of fully analytical paradigm of the verb. Typical modals are polyfunctional in the sense that they express no less than two types of modality. We can distinguish dynamic, deontic and epistemic modality. Modals are polyfunctional, while so called modal content words; i.e. words with modal meaning, which are not subject to an auxiliarisation process, have only ONE modal mean- 
ing. Let us compare the fully-fledged modal auxiliary Slovene moči 'can' with the modal content word umeti 'to be capable'. The former can express 'capability' (dynamic), 'objective possibility' (dynamic), and 'perhaps' (epistemic), while the latter is confined to 'capability'.

A typical modal is part of the predicate and usually does not occur in other syntactic positions, it does not select its own nominal arguments but takes over the argument structure of the verbal form, and, therefore, it does not influence the selection of the subject. Therefore, modals usually can be combined with human and nonhuman subjects. This explains why personal modals allow passive transformations without a change in meaning:

(5) Moramo izdelati dokumentacijo. 'We must work out the documentation.'

(5') Dokumentacija mora biti izdelana. 'The documentation must be worked out.'

The Slovene modal system is characterised by the opposition between modals which agree with the subject ('personal modals') and those modals which, being restricted to the third person, do not allow a subject in the Nominative case ('impersonal modals'). We have found the following three syntactic types:

$$
\text { Type I: } \mathrm{N}_{\text {Nominative }}+\mathrm{AUX}_{\text {modal }}+\mathrm{V}_{\text {infinitive }}
$$

This is the most regular type of modal because it can co-occur with any type of verb. It does not impose any selection restrictions on the verb. This structure allows avalent verbs and verbs with non-human first arguments.

(6) Moralo bi deževati. 'It is supposed to rain.'

(7) Izpit mora trajati dve uri. 'The exam is supposed to last two hours.'

$$
\text { Type II: } \mathrm{N}_{\text {Null }} / \mathrm{N}_{\text {Dative }}+\mathrm{AUX}_{\text {modal }}+\mathrm{V}_{\text {infinitive }}
$$

Some modals form an impersonal construction where the predicate is in the third person singular neuter and the first argument of the infinitival verb can be expressed either in the dative case or as null.

(8) Moje stališče je, da se nam v Evropo ni treba vračati, ker smo v njej vedno že bili. (Mladina) 'From my point of view we don't need to return to Europe, because we have always been there.'

(9) Treba je delati to, da Sarajevo ne bo več geto, in ne to, da se v getu dogaja kultura. (Mladina) 'It is necessary to do something so that Sarajevo doesn't remain a ghetto and not that cultural events take place in the ghetto.'

$$
\text { Type III: } \mathrm{N}_{\text {Nominative }}+\mathrm{AUX}_{\text {modal }}+\mathrm{V}_{\text {finite }}
$$

Apart from modal construction with infinitival verbs Slovene has a modal governing a finite verbal form:

(10) Peter lahko vstopi. 'Peter can go in.'

(11) Izpit lahko traja dve uri. 'The exam may last two hours.' 


\section{CuRRENT STATE OF RESEARCH}

While the modal systems of other Slavonic languages have been described in some detail, ${ }^{1}$ there is little to find on Slovene modals. Mečkovskaja (1994) gives a general overview of the modal system, however, one of the more interesting elements, the modal $n a j$, has hardly been investigated, although some interesting information is found in the articles of Messner (1980) and Gradišnik (1981). Lenček (1968) provides us with a helpful study on the modal use of lahko. A Polish-Slovene contrastive approach on modal verbs can be found in Babula (1980), while Hansen (1998) delivers an initial treatise on Slovene modals. As modality is usually treated as a lexical phenomenon, standard grammars give only limited information on the topic. Hitherto, there has been no attempt to describe Slovene modals in the framework of grammaticalization theory.

\section{Modals in SLovene}

An extensive corpus investigation was necessary in order to identify and classify the elements forming the category of modals in the Slovene language. The research is primarily based on material found in the synchronic reference corpus NOVA BESEDA, compiled at the Fran Ramovš Institute of Slovene, Slovene Academy of Science and Arts (http://bos.zrc-sazu.si/s_beseda.html), in the online corpus FIDA (www.fida.net) as well as in its follow-up project FIDAPLUS (www.fidaplus.net). FIDA and FIDAPLUS are both compiled under the auspices of the Philosophical Faculty of the University of Ljubljana. The majority of the samples are taken from FIDAPLUS, which contains a broad variety of scientific texts, journalistic material, fiction (original Slovene as well as translated) and a small amount of spoken Slovene (notes of parliamentary debates). Some examples have been derived from the Slovar slovenskega knižnjega jezika (SSKJ) and some are constructed. In the latter case sentences have been checked by native speakers. Data for Russian and other languages are based on Hansen 2001. In the following sections, we will describe the fully-fledged modals lahko, moči, utegniti, morati and treba. Apart from that, we will discuss the elements at the periphery of the category. We do not intend to give an exhaustive list of all lexical elements with modal meaning. The short lexicographic portraits focus on the following aspects: semantic polyfunctionality, syntactic structure and behaviour in respect to negation. The portraits take into consideration all meanings of the relevant surface units, including non-modal meanings. This is important because modals may retain their original pre-modal meanings or may develop new so-called post-modal meanings (terms by van der Auwera - Plungian 1998). Each lexicographic portrait starts with a list of meanings illustrated by exam-

\footnotetext{
${ }^{1}$ For an overview see Hansen 1998 and 2001.
} 
ples, contains a discussion of the individual lexemes and their syntactic behaviour and ends with a short characterisation of the element in terms of the proposed definition of a modal. The structure of section 3 is as follows: 3.1. Possibility: modals (lahko, moči, utegniti), 3.2. Possibility: semi-modal smeti; 3.3. Necessity: modals (morati, treba), 3.4. Necessity: semi-modal naj.

\subsection{Possibility: MODALS}

\subsubsection{LAHKO}

Syntactic structure of the modal: $\mathrm{N}_{\text {Nominative }}+\mathrm{AUX}_{\text {modal }}+\mathrm{V}_{\text {finite }}$

lahko 1a 'capability'

(12) Nam pa je dobro znano, da Celje lahko bije s svojo silo dva Habsburga in s svojim zlatom kupi si Benečijo. (A. Novačan) 'It is well known that Celje can defeat two Habsburgs with its power and buy Venice with its gold.'

lahko $1 \mathrm{~b}$ 'objective possibility'

(13) Tu smo lahko srečali celo skupino ruskih turistov, ki so se med bivanjem v mestu se temeljito namočili v Fontani. (Delo) 'Here we were able to meet an entire group of Russian tourists who refreshed themselves thoroughly in the fountain during their stay in the city.'

lahko 1c 'permission'

(14) Trgovci se lahko odločijo za znižanje cen v razponu [...]. (Delo) 'The merchants may decide to reduce the prices gradually [...].'

lahko 2 'medium probability'

(15) Lahko bi se zgodilo, da bi v bližnji prihodnosti veliko moških ostalo brez žene. (Delo) 'It may happen in the near future that many men will be without women.'

lahko 3 'concessive marker'

(16) Lahko je bogat, srečen pa ni. 'He may be rich, but he is not lucky.'

lahko 4 'lightly, easily’ (pre-modal meaning) Adv + V 
(17) Po drugi strani pa so ljudje (...) navajali, da so spali samo rahlo in so se precej lahko zbudili. (Delo) 'On the other hand there are people (...) who stated that they slept only lightly and awoke easily.'

The modal lahko represents a specific feature of Slovene and does not possess a structural equivalent in any other Slavonic language ${ }^{2}$. It covers the same levels of modal meanings as Russ. мочь and Serb./Cro. moći. Being the adverb of lahek 'light, easy' it has undergone a grammaticalization process and eventually became the most frequent modal in Slovene (35. place in the frequency list of the online corpus FIDA). While keeping its pre-modal meaning 'lightly, easily' (lahko 4), lahko has largely replaced the universal modal moči. As an expression of modality, lahko first appeared in the spoken language and later substituted the verbal modal in the written language (see Lenček 1968: 128). ${ }^{3}$ Unlike other Slavonic modals, lahko combines with finite verbs. ${ }^{4}$

The following example demonstrates the semantic bridge between the pre-modal meaning 'lightly, easily' and the modal function 'can' or 'may'.

(18) Da, rad bi vedel, odkod naj vzamem veselja, če ga ni v meni; Tebi je lahko govoriti [...] (I. Cankar). 'Yes, I would like to know from where I can take happiness, if it is not inherent in me. For you it's easy / you can say that $[\ldots]$ '

Like Serb./Cro. moći, lahko can simultaneously activate two levels of modality, which means there are contexts in which the reading 'capability' can be considered as well as 'objective possibility' (see Hansen 2001: 74). Apart from the modal meaning, lahko in some contexts bears a concessive function (lahko 3).

On the pragmatic level, lahko is used to make a polite request. In these constructions, intonation plays a major role (Lenček 1968: 128 f.).

(19) Ali mi lahko daš kozarec vode? 'Could you get me a glass of water?'

Elliptic constructions with the omission of the verb are frequent, especially in requests and permissions. In elliptic constructions with verbs of motion, the verb is implied in the modal:

(20) V kino bi šel, mama. A lahko? - Lahko! 'I would like to go to the cinema, Mum. May I? - You may!'

(21) Danes to ni težko. Vsak je lahko na akademiji, samo ti ne. (D. Jančar) 'Today it isn't difficult. Everybody can (go) to the Academy, only you (may) not.'

${ }^{2}$ Etymologically related are Russ. нельзя and Cz. lze (see Snoj 2000). These are, however, used with a verb in the infinitive.

3 Lenček still classifies phrases with lahko mainly as a structure of the spoken language and mentions that there has been an increasing adoption in the written language (1968: 128 ff.). This shows that this process has developed recently.

4 With the exception of syntactic constructions with finite verbs in Serbian like on može da dođe (see Hansen 2001: 243). 
The epistemic meaning lahko 2 is mostly expressed by the conditional:

(22) Lahko bi se zgodilo, da bi se slovenska vojska v skladu z Natovimi standardi profesionalizirala in zmanjšala s 63.000 na 35.000 mož. (Delo) 'It may happen that the Slovene army will professionalize itself according to NATO standards and will diminish from 63.000 to 35.000 men.'

In this function, lahko can govern a subordinated clause with and without $d a$ :

(23) Lahko (da) pride, lahko (da) ne. 'Maybe he'll come, maybe not.'

The modal lexemes lahko 1 and 2 cannot be negated. Dynamic and epistemic impossibility is expressed by ne moči and prohibition by ne smeti.

(25) A mi lahko pomagaš pri testu? Ja, lahko. / Ne, ne morem. / Ne, ne smem. 'Can you help me with the test? Yes, I can. / No, I am not able to do that. (dyn.) / No, I am not allowed to do that. (deo.)'

Summary: Lahko has all constitutive features of a fully-fledged modal. It includes all three types of modality and does not impose any restrictions on the first argument of the verb. However, lahko retains its original lexical meaning of 'lightly, easily' (lahko 4). On the one hand, the modal meanings have departed so far from the adverb lahko 4 that we are dealing with a complete split from the pre-modal meaning.

\subsubsection{MoČI}

Structure $\mathrm{N}_{\text {Nominative }}+\mathrm{AUX}_{\text {modal }}+\mathrm{V}_{\text {infinitive }}$

moči 1a 'capability'

(1) [...] le obtoženčeva žena oziroma stara mati nesrečnega dekletca ne more doumeti resnice. (Delo) '[...] only the accused woman, i.e. the grandmother of the unhappy child, was unable to understand the truth.'

moči $1 \mathrm{~b}$ 'objective possibility'

(2) Ljudje so dojeli, da jih je hrvaško vpletanje v notranje zadeve BiH oddaljilo od številnih evropskih držav in ZDA. Hrvaška ne more v Evropo brez trdne in neodvisne $\mathrm{BiH}$. (Delo) 'The people understood that Croatian involvement into the inner affairs of $\mathrm{BiH}$ separates it from the position of numerous European states and the USA. Croatia cannot join Europe without a strong and independent BiH.'

moči 2 'medium probability' 
(3) Mnogi mislijo, da če se kdo preoblači v žensko, že ne more biti normalen. (Mladina) 'A lot of people think if somebody dresses up like a woman he can't be normal.'

Concerning form, Slovene moči resembles Russ. мочь and Serb./Cro. moći, yet it differs substantially in use. The affirmative use of moč $i$ has been almost completely replaced by lahko with the result of an almost complementary distribution. Non-negated moči is stylistically marked and considered as literary (see Toporišič 1982: 234) except in non-affirmative contexts like conditional sentences or constructions which indirectly imply condition or negation (such as questions with kako 'how', phrases with komaj 'hardly', le 'only' etc.) where the use is standard. To give some examples:

(26) Predlagam, da bi kar pričeli, je podvizal Jugoslovan in se razgledal, če $b i$ mogel kje naročiti kakšno pijačo. (I. Karlovček) 'I would suggest that we start now, the Yugoslav said and looked around to see if he could order a drink.'

(27) Kako ti more kaj takega sploh priti na misel? 'How can you come up with a thing like that?'

(28) Vode popijemo, kolikor moremo. 'We drink as much water as we can.'

In contrast to Russ. мочь and Serb./Cro. moći, Slov. moči generally does not have a deontic meaning which is expressed only by lahko and smeti, or in negative sentences by ne smeti. Moči can appear with external and double negation. Unlike Russ. мочь (see Hansen 2001: 175), it does not permit internal negation $\left(\diamond \neg\right.$ p). ${ }^{5}$

External negation: $X$ ne more $\mathrm{p}(\neg \diamond \mathrm{p})$

(29) Skratka, če ste ljubitelj narave, vam na Dolenjskem ne more biti dolgčas. (Krka zdravilišča) 'In short, if you are a nature lover you won't get bored in Dolenjska'.

Double negation: $\mathrm{X}$ ne more ne $\mathrm{p}(\neg \diamond \neg \mathrm{p})$

(30) Sprašujem se, koliko bi jih v resnici prišlo v Genovo, če ne bi bilo mika obojestranskega nasilja, ki so ga vsi scenaristi tako jasno pripravili, da se skoraj $n i$ moglo ne zgoditi. (DELO) ${ }^{6}$ ' I asked myself how many people would have come to Geneva if there weren't the incentive of participating in violent acts by both sides, which were so obviously prepared by all participants that it would have been impossible that nothing happened.'

An elliptical use of moči is also possible: ni mogel na hrib 'he could not (climb) the hill'. In the epistemic meaning, moči usually appears in the conditional:

${ }^{5}$ In formal notation, $\diamond$ denotes possibility, $\neg$ negation and $\square$ necessity.

6 This construction with double negation, bearing the meaning 'can not avoid doing sth.' should not be confused with the following: On ne more ne umreti, ne živeti. 'He cannot live nor die'. 
(31) Morda bi mogli dobiti kak odgovor tudi s hrvaškega poslaništva v Sloveniji? (Delo) 'Maybe one could get some answer from the Croatian embassy in Slovenia?'

Furthermore, there are two peripheral fully lexical meanings of moči which form idiomatic expressions: 'to be responsible' and 'to do harm to sb.':

(32) Bridges je skomignil. Kaj jaz morem za to? (Pogačnik) 'Bridges gave a shrug. I can't help it, can I?'

(33) Nič me ne morejo! 'They can't do any harm to me!'

Similar to Russ. смочь, the Slovene verb zmoči appears to be the aspectual partner of moči. However, it differs from moči because it not only describes an nonobservable state of being able to do something, but also an action which has already been completed or remains to be carried out (see for смочь van der Auwera Plungian 1998 and Hansen 2001). Zmoči is close to English 'to manage to do sth.'. Like its Russian cognate, zmoči does not bear deontic or epistemic meanings.

(35) Prezaposlena $\mathrm{z}$ vsakdanjimi utrujajočimi boji s centrom in prepričana, da je rešitev v obrambi avnojske Jugoslavije (ustave iz leta 1974), slovenska politika ni zmogla koncipirati konsistentnega nacionalnega programa. (Delo) 'Overworked with the daily exhausting struggle with the centre and convinced that the solution lies in the defence of AVNOJ-Yugoslavia (the constitution from the year 1974), Slovene politics was not able to set a consistent national programme.'

The modal moči is to be distinguished from the derivates moči/moč with dynamic and morebiti/morda with epistemic meaning.

(36) Oboje je bilo moči dobiti. 'It was possible to get both of them.'

(37) Povedala je vse, morebiti še več, kakor je treba. 'I told everything, maybe more than necessary.'

(38) Hannawald morda nikdar ne bo postal zmagovalec skakalnega svetovnega pokala. (Delo) 'Hannawald perhaps will never become a world champion in ski-jumping.'

Summary: Moči occurs like its Russian cognate мочb with a main verb in the predicate position and does not impose selection restrictions on the verb (see for мочь Hansen 2001: 173). It is defective as it lacks an imperative form and a direct aspectual partner and shows only weak traces of its original full-lexical meaning. Therefore, mос́ $i$ is like мочь a prototypical modal, though less polyfunctional as it lacks deontic meaning.

\subsubsection{UTEGNITI}

Structure $\mathrm{N}_{\text {Nominative }}+\mathrm{AUX}_{\text {modal }}+\mathrm{V}_{\text {infinitive }}$

utegniti 1 'to be able to do sth because of availability of time' 
(39) Izraelski ministrski predsednik bi moral obiskati ZDA pred nekaj tedni, a ni utegnil zaradi napetih dogodkov na Bližnjem vzhodu. (Delo) 'The Israeli prime minister could have visited the United States some weeks ago, but did not make it due tense incidents in the Near East.'

utegniti 2 'medium probability'

(40) Če bo Hrvaška Haagu izročila svoje generale, utegne v državi zavladati kaos, [...] 'If Croatia delivers its generals to The Hague, the country could fall into chaos $[\ldots]$ '

Utegniti is a modal that includes the reference to available time. Additionally, the element works on the epistemic level without this temporal component. This epistemic use is marked as formal. Because of its covering of different modal levels and its syntactic behaviour (no selection restriction for the subject), utegniti meets all requirements for a prototypical modal, although it is less frequently used than other modals. Utegniti has no cognate forms in the contemporary use of other Slavonic languages, except the dialectical Croatian utegniti 'to have time'. In Old Church Slavonic utegnoti is found bearing the same meaning (see further Snoj 2003: 802).

\subsection{POSSIBILITY: SEMI-MODAL SMETI}

Structure $\mathrm{N}_{\text {Nominative }}+\mathrm{AUX}_{\text {modal }}+\mathrm{V}_{\text {Infinitive }}$

smeti 'permission'

(41) Vendar zakon pravi, da sme samo policija proti zločincu uporabiti silu. (Delo) 'But the law says that only the police are allowed to use force against a criminal.'

(42) Zadolževanje države dolgoročno ne sme rasti hitreje od narodnega dohodka 'On the long run the national depth must not grow faster than the national income.' (Delo)

Similar to moči, smeti is used mainly in non-affirmative contexts. Deontic modality in positive clauses is usually expressed by lahko. Non-negated smeti frequently appears in specific polite contexts and puts more emphasis on the request for permission than lahko (compare Derbyshire 1993: 109).

(43) „Sabijn, kakšno presenečenje! Smem predstaviti, to je Tobias.” (A. Morovič) 'Sabine, what a surprise! Let me introduce you, this is Tobias!'

Slov. smeti has no further non-modal meanings, differing from Serb./Cro. $s m(j) e t i$, which besides 'to be allowed to' also means 'to dare'.

Although allowing non-animated subjects, smeti has to be considered a peripheral or semi-modal because it is not polyfunctional. 


\subsection{NeCESSITY: MODALS}

\subsubsection{Morati}

Structure $\mathrm{N}_{\text {Nominative }}+\mathrm{AUX}_{\text {modal }}+\mathrm{V}_{\text {infinitive }}$

morati 1a 'objective necessity'

(46) Pripraviti se bodo morala tudi na konkurenco, ki je zdaj še nimajo. (Delo) 'They must also prepare for the competitors which they do not have yet.'

morati $1 \mathrm{~b}$ 'inner necessity'

(47) Še nekaj te moram vprašati. 'There's something else I have to ask you.'

morati 1c 'obligation'

(48) Naš sveti oče, papež Pavel VI, je izdal pred tremi leti odredbo, da mora vsako knjigo v narodnih jezikih odobriti sveta inkvizicija. (D. Jančar) 'Our holy Father, Pope Paul VI, passed an ordinance three years ago whereby the holy inquisition has to approve every book in a national language.'

morati 2 'high probability'

(49) To mora biti pravi Slovenec, ni dvoma. V Nemčiji namreč česa takega še nisem videl. (Delo) 'That must be a real Slovene, no doubt. Because in Germany I haven't seen anything like this yet.'

As to semantics, the Slovene lexeme morati is quite similar to Serb./Cro. morati and Pol. musieć. It has expanded to all three levels of modality, does not show any non-modal meanings and is neutral towards the subject; i.e. it allows human and non-animated subjects:

(50) Poljsko gospodarstvo bi se moralo razvijati v smeri toplega, človeškega liberalizma. (Delo) 'The Polish economy is supposed to develop in the direction of a warm and humane liberalism.'

In contrast to Serb./Cro. morati, which permits external negation, morati does not allow any negation. Negated necessity is expressed by ni treba $(\ulcorner\square \mathrm{p})$ :

(51) Ne potrebujejo šole o tem, kako mine izgledajo. Tudi jih ni treba učiti, kako mine pobrati, saj so konec koncev vse mine oni postavili. (Delo) 'They don't need to learn what a mine looks like. And you also needn't teach them how to sweep for them, because, ultimately, all mines were laid by them.' 
Internal negation is expressed by ne smeti (according to the universal logical equivalence $\square\ulcorner\mathrm{p}=\neg \diamond \mathrm{p}$ ):

(52) Agent v službi ne sme občutiti mraza, marveč mora goreti v žaru navdušenja! (A. Ford) 'An agent in duty must not feel any cold, but must burn with the flames of enthusiasm!'

In connection with verbs of motion, the infinitive can be omitted:

(53) Moraš k zdravniku! 'You have to see the doctor!'

Summary: Because of the above-mentioned features - i.e. modal polyfunctionality and lack of selection restrictions - morati can be regarded as a fully-fledged modal.

\subsubsection{TREBA}

Structure of the modal $\mathrm{N}_{\text {Null }} / \mathrm{N}_{\text {Dative }}+\mathrm{AUX}_{\text {modal }}+\mathrm{V}_{\text {infinitive }}$

treba 1a 'objective necessity'

(54) Barbara Kolar [...] je še razložila, da bo treba nekatere poskuse vedno opraviti na više razvitih živalih [...] (Delo) 'Barbara Kolar [...] explained that it would be necessary to always carry out some experiments with higher developed animals $[\ldots]$ '

treba $1 \mathrm{~b}$ 'obligation'

(55) Saj vam ni treba čakati, da vlak odpelje, je dejala. (M. Drabble) 'But you needn't wait till the train leaves, she said.'

treba 2 'to need sth.' (non-modal meaning) $\mathrm{N}_{\text {Null }} / \mathrm{N}_{\text {Dative }}+$ treba $+\mathrm{N}_{\text {Genitive }}$

(56) Dajte mi sto goldinarjev. V Mirni peči me čaka gospod, treba mi je denarja. (J. Trdina) 'Give me a hundred guilders. In Mirna Peč a gentleman is waiting for me, I need money.'

In regard to syntax and semantics, treba resembles the Russian modal надо. In contrast to Serb./Cro. trebati, a modal with maximum semantic expansion and a high variety of syntactic constructions, Slov. treba and Russ. надо cover only two modal levels, can be used only in impersonal constructions and are restricted to verbs with a human first argument. Both permit a logical subject in the dative. In affirmative phrases with treba 1 a logical subject in the dative is rare, but standard in negated phrases. The object of the non-modal lexeme treba 2 'to need sth.' is in the genitive, equal to constructions with надо (for надо see Hansen 2001: 187 ff.). 
treba 1 - impersonal construction without subject:

(9) Treba je delati to, da Sarajevo ne bo več geto, in ne to, da se v getu dogaja kultura. (Mladina) 'It is necessary to do something so that Sarajevo doesn't remain a ghetto and not that cultural events take place in the ghetto.'

treba 1 - impersonal constructions with logical subject in the dative (negated):

(8) Moje stališče je, da se nam v Evropo ni treba vračati, ker smo v njej vedno že bili. (Mladina) 'From my point of view we don't need to return to Europe, because we have always been there.'

Treba je can govern a subordinated clause with $d a$; these constructions, however, are rare and seem to be obsolete according to the low number of references in FIDAPLUS. Also in respect to this fact treba resembles Russ. надo, as constructions with надо + чтобы and subordinated clause are also possible but rare (see Hansen 2001: 188). The examination of the Slovene references shows that treba je $+d a$ is mainly used to express moral-religious precepts. Therefore, we are dealing with a situation which is marked in the same manner as in Russian constructions with надо + чтобы, i.e. a specific personal situation in which usually a collective functions as the deontic source (compare ibid.).

(58) Dober napredek z vašim delom, treba je da današnja mladina ne pozabi, da lahko zahvalijo našega dragega maršala Tita za vse kar imajo. (Mladina) 'A good progress in our work, our youth of today must not forget that they can thank our dear Marshall Tito for everything they have.'

As already mentioned above treba functions as an expression for negated necessity and replaces morati which cannot be negated. Treba permits only external negation $(\neg \square \mathrm{p})$.

(59) To je moja zasebna stvar in mi jo vam ni treba povedati! (Mladina) 'That's my personal business and I don't have to tell you about it!'

Treba 1 often occurs negated when somebody is directly addressed, similar to Russ. надо. However, this usage does not express a strict demand to cease an action as it is the case in Russian (Hansen 2001: 188), but a polite advice or a simple reference to absent necessity or obligation.

(60) Ni vam treba misliti, da tega ne vemo. 'You don't have to think that we don't know that.'

(61) Jaz vas spremim, prijatelji. - Ni treba. Kdo bo stražil tvoj denar? (F. Deleta) 'I accompany you, my friend. - That's not necessary. Who will watch over your money?' 
Despite the expansion on two modal levels treba is a slightly less grammaticalized modal because it is restricted to verbs with a human first argument.

\subsection{NeCESSITY: SEMI-MODAL NAJ}

Structure $\mathrm{N}_{\text {Nominative }}+\mathrm{AUX}_{\text {modal }}+\mathrm{V}_{\text {finite }}$

naj 1 'uttered weak obligation'

naj 2 'hear-say'

naj 3 'thought intention'

naj 4 'marker for conditional'

various other functions

The particle naj functions in the field of weak necessity (cf. the meaning of English should). It is of enigmatic semantics and possesses several grammatical functions. Naj is the reduced form of *nexaj, the imperative of *nexati ( $\rightarrow$ nehati) 'to let, to allow' (Snoj 2000: 369) and therefore close to Serb./Cro. neka and Russ. nycmb ${ }^{7}$. The former imperative marker underwent a grammaticalization process towards a word with diffuse semantics.

One grammatical function of $n a j$ is the construction of a specific analytic imperative ('želelnik' or 'optative') in some grammars, i.e. older Slovene grammars and some newer non-Slovene, classified as a mood distinct from indicative, conditional and imperative ${ }^{8}$. This so called 'optative' expresses a wish, advice or a weak command on behalf of the speaker (Bajec 1956: 217). In contemporary Slovene linguistics, the concept of the optative is regarded as outdated. We take the stance that in this case the borderline between mood and modal is fluid.

The range of uses of naj is much broader than the one of Russ. nycmb and has clear parallels to the Polish modal mieć (for mieć see Hansen 2001: 133; a mention of the correspondence of mieć and naj is also found in Babula 1980: 114). Hence, in the following the same means of description as for the other modal expressions is used for $n a j$, regardless of the fact that some constructions can also have an impera-

${ }^{7}$ For the analytic imperatives with these forms and their grammaticalization see Hansen 2004.

8 So Herrity 2000: 189 ff., Bajec 1956: 217 f., Derbyshire 1993: 82 and Vincenot 1975: $231 \mathrm{f}$. Toporišič 2004: $396 \mathrm{f}$., however, considers these forms part of the imperative paradigm. Similar discussions are familiar from other Slavonic languages, e.g. concerning the question whether elements like Russ. nycmb should be treated as part of the imperative paradigm or not (see Hansen 2004). 
tive-like reading and that conventional grammars do not place naj in the group of modal expressions like e.g. lahko, treba, morati.

Naj does not impose any restrictions on the subject, but usually accompanies only the first and third person in all three numbers ${ }^{9}$ in the present tense, the conditional and the future of biti. It has to be pointed out that these restrictions in respect to person and tense are not typical of modals: e.g. morati can be used in all three persons and has a past tense form. Naj 1 can be described by the same lexicographic explication, suggested by Hansen for Pol. mieć 1 (Hansen 2001: 135):

naj 1 naj $X p$ : 'IT IS BETTER IF X DOES P, BECAUSE Y SAYS OR SAID OR IS GOING TO SAY THAT Z WANTS X TO DO P'

In the same manner as Polish mieć expresses a weaker degree of compulsion than musieć and trzeba (ibid.), an obligation formed with naj is also weaker than one which is expressed by morati or treba (compare Bajec 1956: 217 „omiljeno zapoved ali prepoved"). Therefore, the explication contains the element IT IS BETTER IF. Naj expresses a direct or indirect repetition of a professed intention. The participants of the communicated situation $\mathrm{X}, \mathrm{Y}$ and $\mathrm{Z}$ may be identical to the speaker or a third person, however, only $\mathrm{Y}$ and $\mathrm{Z}$, but not $\mathrm{X}$ may be identical to the addressee. This results in different readings depending on the constellation, among these:

\section{Demand: IT IS BETTER IF HE DOES P, BECAUSE I SAID THAT I WANT HIM TO DO P'}

(65) Zbudite mi Heriča. Naj nemudoma sedla najboljše konje, naj pohiti za mojim sinom Hermanom in naj mi ga pripelje, če je še živ ... (A. Novančan) 'Wake Herič up! He shall immediately saddle the best horse, he shall hurry after my son Herman and shall bring him back, if he is still alive ...'

\section{Intention: IT IS BETTER IF I DO P, BECAUSE I SAY THAT I WANT TO DO P'}

(66) Naj odkrito odgovorim, da se s tem ne obremenjujem. (Dnevnik) 'I want to answer frankly that I don't want to take that on.'

If speaker and target of the 'weak obligation' coincide naj does not correspond to English shall or German sollen, but can be translated only with want or möchten/wollen. ${ }^{10}$

Request for advice: 'IT IS BETTER IF I DO P, BECAUSE YOU WILL SAY THAT YOU WANT ME DO P'

${ }^{9}$ In some cases also $n a j+2$. person is possible, e.g. in questions of the following type: $K a j$ naj storiš, me vprašaš? 'You ask me, what I should do?'. In colloquial language naj +2 . person can be used to express the regular imperative (Bajec 1956: 217).

10 A similar situation occurs with Pol. mieć in the reading 'must' (compare Hansen 2001: 135 and 140). 
(67) “Kaj naj naredim s teboj," je rekla Imaquawaq ženski, “oropala si moje čebele. Naj te zapletem v veje mojega domovanja, da te bodo lahko moje čebele popikale do smrti?" (H. Artmann) 'What shall I do with you, said Imaquawaq to the woman, you have plundered my bees. Shall I weave you into the branches of my home, so that my bees sting you to death?'

Where naj appears to be a conjunction, its usage in fact reflects a direct transition of a professed intention, uttered in direct speech, into a subordinated clause in indirect speech. Also these constructions can be subsumed under the abovementioned description.

IT IS BETTER IF X DOES P, BECAUSE SOMEONE ELSE SAID THAT HE WANTS X TO DO P.

(68) Okrog enajstih se je pojavil bivši župan Rastrg in Edvini ponujal, naj stopi v Združenje krščanskih podjetnikov. (Delo) 'Around eleven the former mayor Rastrg appeared and advised Edvina to join the Society of Christian Entrepreneurs.'

Naj 1 permits only internal negation $(\square \neg \mathrm{p})$ :

(69) Ko gre nekdo v politiko, naj občutljivo dušo, ki trpi ob vsakem očitku, pusti doma. Ali pa naj ne hodi v politiko. (Mladina) 'If somebody goes into politics, he should leave the sensitive soul, which suffers from each accusation, at home. Or he should not go into politics.'

In contrast to the modal morati, naj does not allow ellipses of the non-finite verb: (70) *Najkzdravniku! - Naj gre k zdravniku!; 'He should see the doctor!'

Naj 2: A non-modal function of naj distinct from naj 1 is the repetition of information, which the speaker learned by hear-say. In these cases, naj appears with the conditional and corresponds to the evidential meaning of Pol. mieć and Germ. sollen (Hansen 2001: 137).

\section{naj 2 naj $X p$ 'SOMEONE TOLD THE SPEAKER THAT X DOES P.'}

(71) Včeraj pa so jo našli mrtvo prav v bližini lokala, kjer so jo nazadnje videli živo. Po prvih ugotovitvah naj ne bi umrla nasilne smrti, vendar bo več znanega potem, ko bo končana obdukcija. (Delo) 'But yesterday the body was found near the restaurant in which he was seen alive at last. According to primary investigations he is said to have died by violence, although more will be known after the postmortem.'

Gradišnik (1981: 24) points out that the expansion of the element into the evidential field could have happened through expressive sentences of the spoken language like the following: 
(73) Sram vas bodi. In to naj bi bila slovenska kultura! (Mladina) 'Shame on you! And this is meant to be the Slovene culture!'

Naj can also be used as an introduction of a final clause, which expresses an unspoken intention of the subject of the main clause. Naj corresponds here to a final 'so that'. We assume that in these cases we are dealing with an expansion of the particle on an unspoken but thought professed intention.

(74) Fanta skrij, naj ga nihče ne vidi. 'The boy hides to be invisible.'

We suggest the following explication:

$n a j 3-X p$, naj $q$ : 'X DOES P; BECAUSE X WANTS THAT Q AND IF X DOES P, THEN Q.'

Similar to Pol. mieć, naj became a marker not only of evidentiality but also of conditionality, as it marks real conditions with the feature 'the speaker assumes $\mathrm{p}$ as not very likely' (compare for mieć Hansen 2001: 138).

\section{naj 4 'IF $\mathrm{X}$ DOES P, WHERE THE SPEAKER ASSUMES THAT P IS NOT VERY LIKELY'}

(75) Naj te kdo vidi, kriči! 'Should anybody see you, shout!'

Naj possesses, especially in the pragmatic field, a variety of functions in addition to the above described which might be worth a separate analysis.

Summarizing the analysis, we can stress: $N a j$ is a highly polyfunctional element which possesses one modal and some post-modal meanings (deontic, evidential and conditional) and which shows no selection restrictions. Therefore, we can consider it a semi-modal located at the periphery of the category.

\section{CONCLUSION}

We have offered a description of Slovene modals based on a cross-linguistic definition of the category. We have identified five elements fulfilling all criteria of a fully-fledged modal: lahko, moči, utegniti, morati and treba. They show clear characteristics of grammatical markers. None of the Slovene verbs with volitional meaning meet the requirements of a modal. They are not polyfunctional in the field of modality and do not allow non-animated subjects. 
Overview table

\begin{tabular}{|c|c|c|c|c|}
\hline & Modal meanings & $\begin{array}{l}\text { Selection } \\
\text { restrictions }\end{array}$ & Polarity & Status \\
\hline lahko & $\begin{array}{l}\text { Possibility: dyna- } \\
\text { mic, deontic, } \\
\text { epistemic }\end{array}$ & $\overline{\varnothing \varnothing}$ & "affirmative & $\begin{array}{l}\text { fully-fledged } \\
\text { modal }\end{array}$ \\
\hline moči $i$ & $\begin{array}{l}\text { Possibility: dyna- } \\
\text { mic, epistemic }\end{array}$ & $\varnothing$ & non-affirmative & $\begin{array}{l}\text { fully-fledged } \\
\text { modal }\end{array}$ \\
\hline utegniti & $\begin{array}{l}\text { Possibility: dyna- } \\
\text { mic, epistemic }\end{array}$ & $\varnothing$ & $\varnothing$ & $\begin{array}{l}\text { fully-fledged } \\
\text { modal }\end{array}$ \\
\hline morati & $\begin{array}{l}\text { Necessity: dyna- } \\
\text { mic, deontic, } \\
\text { epistemic }\end{array}$ & $\varnothing$ & affirmative & $\begin{array}{l}\text { fully-fledged } \\
\text { modal }\end{array}$ \\
\hline treba & $\begin{array}{l}\text { Necessity: dyna- } \\
\text { mic, deontic, }\end{array}$ & + human & non-affirmative & $\begin{array}{l}\text { less grammati- } \\
\text { calized modal }\end{array}$ \\
\hline smeti & $\begin{array}{l}\text { Possibility: deon- } \\
\text { tic }\end{array}$ & $\varnothing$ & $\varnothing$ & semi-modal \\
\hline naj 1 & $\begin{array}{l}\text { Necessity: deon- } \\
\text { tic }\end{array}$ & $\varnothing$ & $\varnothing$ & semi-modal \\
\hline
\end{tabular}

Apart from that, we have analysed two units sharing some features of a modal (smeti, naj) and some elements with modal meaning which we regard as fully lexical, i.e. non-grammaticalized expressions of modality (umeti, imeti, hoteti, želeti, rad, marati). The analysis shows some peculiarities of the Slovene modal system if compared to the other Slavonic languages. There are two features setting Slovene apart from the other Slavonic languages: 1) the grammaticalization of the adjective lahko which replaced the general modal mocii. The peculiarity of lahko is its syntactic behaviour: it governs finite verbs. 2) The Slovene system is characterised by a strong tendency towards negative and positive polarity items, i.e. the use of different modals in affirmative and in non-affirmative, especially negative contexts; cf. lahko - moči/smeti and morati - treba. From an areal perspective, it is interesting to note that the Slovene modal system differs considerably from the German one, which is based on personally constructing verbs (cf. Hansen 2005, van der Auwera et al. 2005). We will leave to future research the question how this specific Slovene system historically came into existence and which role language contact played.

\section{Re f e r e n c e s}

Babula 1980: $\quad$ E. Babula, Modalni glagoli v izvirnem besedilu Mickiewiczevega Gospoda Tadeja in njihovi ustrezniki v slovenskem prevodu, Jezik in Slovstvo 1980-1/3, 110-114

Bajec - Kolarič - Rupel 1956: A. Bajec, R. Kolarič, M. Rupel, Slovenska slovnica, Ljubljana Debenjak 1994: $\quad$ D. Debenjak, Veliki nemško-slovenski slovar, Elektronska izdaja Verzija 1.0

Debenjak 2003: $\quad$ D. Debenjak, Veliki slovensko-nemški slovar, Ljubljana

Derbyshire 1993: $\quad$ W. W. Derbyshire, A Basic Reference Grammar of Slovene, Columbus 
Gradišnik 1981:

Hansen 1998:

Hansen 2001:

Hansen 2004:

Hansen 2005:

Hansen 2006:

Heine 1993:

Herrity 2002:

Jenko 2000:

Lenček 1968:

Mečkovskaja 1994:

Messner 1980:

Nartnik 1968:

Plungjan 2003:

Roeder 2005:

Snoj 2003:

SSKJ:

Toporišič 1982:

Toporišič 1992:

Toporišič 2004:
J. Gradišnik, Domneve z 'naj', Jezik in Slovstvo 1981-2/1, 23-24

B. Hansen, Modalauxiliare in den slavischen Sprachen, Zeitschrift für Slawistik 43/3, 249-272

B. Hansen, Das slavische Modalauxiliar - Semantik und Grammatikalisierung im Russischen, Polnischen, Serbischen/Kroatischen und Altkirchenslavischen, München

B. Hansen, The grammaticalization of the analytical imperatives in Russian, Polish and Serbian/Croatian, Die Welt der Slaven 2004/49, 257-274

B. Hansen, How to measure areal convergence: a case study of contact-induced grammaticalization in the German-Hungarian-Slavonic contact area, in: B. Hansen, P. Karlík (eds.), Modality in Slavonic Languages. New perspectives, München, 219-239

B. Hansen, $\mathrm{Na}$ polputi ot slovarja $\mathrm{k}$ grammatike: modal'nye vspomogatel'nye slova v slavjanskich jazykach, Voprosy jazykoznanija 2, 68-84

B. Heine, Auxiliaries. Cognitive forces and grammaticalization, New York

P. Herrity, Slovene: A Comprehensive Grammar, London

E. M. Jenko, Grammatik der slowenischen Sprache, Klagenfurt Celovec

R. L. Lenček, Modalna raba adverba lahko v Slovenščini, in: Zbornik za filologiju i lingvistiku 1968, 127-135

N. Mečkovskaja, Modal'nost' v slovenskom jazyke, in: H. Jachnow et al. (Hrsg.), Modalität und Modus. Allgemeine Fragen und Realisierung im Slavischen, Wiesbaden, 194-219

J. Messner, Zajedalec 'naj', Jezik in Slovstvo 1979-80/7-8, 216

V. Nartnik, Naklonskost oblik, ki izražajo prihodni čas, Jezik in Slovstvo 1968/2, 52-54

V. A. Plungjan, Obščaja morfologija. Vvedenie v problematiku, Moskva

C. F. Roeder, Das Modalauxiliar im Slovenischen und Russischen, Unveröffentlichte Bachelorarbeit, Universität Regensburg

M. Snoj, Etimološki slovar slovenskega jezika, Ljubljana

Slovar slovenskega knižnega jezika (1970-91), Elektronska izdaja 1.0, Ljubljana

J. Toporišič, Nova slovenska skladnja, Ljubljana

J. Toporišič, Enciklopedija slovenskega jezika, Ljubljana

J. Toporišič, Slovenska slovnica, Maribor

van der Auwera - Plungian 1998: J. van der Auwera, V. A. Plungian, Modality's semantic map, Linguistic Typology 2, 79-124

van der Auwera - Schalley - Nuyts 2005: J. van der Auwera, E. Schalley, J. Nuyts, Epistemic possibility in a Slavonic parallel corpus, in: B. Hansen, P. Karlík (eds.), Modality in Slavonic Languages. New perspectives, München, 201-219

Vincenot 1975: $\quad$ C. Vincenot, Essai de grammaire Slovène, Ljubljana

Carolin Firouzeh Roeder,

B.A., MIREES / Istituto per l'Europa Centro-Orientale e Balcanica

Università di Bologna, Via Marchesi 12, 47100 Forlì, Italy,

carolinroeder@web.de

Björn Hansen,

Institut für Slavistik,

Universität Regensburg, Universitätsstraße 31, 93053 Regensburg, Germany,

bjoern.hansen@sprachlit.uni-regensburg.de 